\title{
MICROFINANCE AND RURAL POVERTY ALLEVIATION: A REALITY?
}

\author{
Taofeek Aremu Kasali* \\ Universiti Utara Malaysia \\ Siti Aznor Ahmad \\ Universiti Utara Malaysia \\ Hock-Eam Lim \\ Universiti Utara Malaysia
}

\begin{abstract}
It is a truism that if Microfinance Institutions (MFIs) play their expected role, poverty will reduce and there will be more employment opportunity and adequate economic development particularly in the rural areas. Poverty is more devastating in Sub-Saharan Africa than the rest of the world. This paper examines the contributions of microfinance towards the rural poverty reduction. To achieve this objective, the study adopted multi-stage random sampling technique to collect primary data through the structured questionnaire. A total sample of 1,134 microfinance loan beneficiaries and non-beneficiaries were used as respondents from three (Ogun, Osun and Oyo states) out of six states in South- West Nigeria. Statistical Percentage Techniques were used to describe the characteristics of the sample from the study. The results revealed that microfinance has marginal effects on the rural poor in Southwest Nigeria. Policy makers are advised to provide adequate infrastructural facilities that will encourage MFIs to establish branches in the rural areas. MFIs should endeavor to create more awareness to the rural poor with realistic loan procedure that will encourage the poor to access microcredit loan.
\end{abstract}

Keywords: Economic Development; Poverty; Microfinance Institutions; rural poor; Nigeria.

\section{INTRODUCTION}

Development connotes the activities geared towards the improvement of quality of lives of human beings in raising their level of wellbeing, freedom and capabilities for selfactualization (Todaro and Smith, 2011:5). To make life meaningful therefore implies having access to the basic necessities of life.

\footnotetext{
*Corresponding author: Telephone: +2348037180556. E-mail address: taofeekkasali2012@gmail.com
} 
Poverty is a multi-faceted fabric which involves economic, social, cultural and psychological dimensions. It is a world phenomenon whose consequences are dehumanizing, devastating and traumatic. In the light of this, and recognizing the importance of the devastating effect of poverty and inequality, the awareness is much more favored at the international level of finance and governance. For instance, the World Bank, United Nations (UN) and International Monetary Fund (IMF) have developed various programmes and projects that would improve the life of the poor, ensure health improvement and sustainable growth and development (Ssewamala, et al.,2010) .

It is on record that about half of the world's population (about three billion people) lives on income of less than two dollars a day (Goel and Rishi,2012) while 70 percent of the extremely poor live in rural areas (IFAD, 2011, Mustapha et al,2014). This is also aggravated by the fact that one child out of five living in these poor communities does not live to see his or her fifth birthday! Hence, in September 2000, the United Nations declared Millennium Development Goals (MDGs) in order to ensure global development. The major policy thrust of this program is to make life more meaningful to the poor and downtrodden. By implication, reduction of poverty and hunger is adjudged to be the basic root of all other problem issues focused on MDGs (Kalirajan and Singh, 2009).

Hunger, which shows the inability to obtain minimum calories and protein food in a country, is one of the important dimensions of poverty. According to 2013 World Hunger and Poverty Facts and Statistics, almost one in eight people in the world were affected by malnutrition in 2010-2012. The report further expressed that "almost all the hungry people, 852 million, live in developing countries, representing 15 percent of the population of developing countries". In Sub-Saharan Africa, hunger rises 2 percent annually since 2007. The statistics shows that from Year 2010 to 2012, the population of people affected by hunger increased from 175 million to 239 million. This indicates that nearly one in four Africans are hungry. The number of hungry people also rise from 13 million in 2004 - 2006 to 16 million in 2012 in the Developed regions (FAO, 2012) cited in 2013 World Hunger and Poverty Facts and Statistics. In essence, hunger causes and is both caused by poverty as hungry worker cannot make reasonable production. Poverty and hunger are caused by non-availability of quality food, poor sanitation, malnutrition and poor health standard (Oliveira et al, 2010).

Malnutrition, as an agent of poverty has more damages particularly in children. For instance, malnourished pregnant women give birth to children with low birth weight, high child mortality rate, learning disabilities, mental retardation, blindness and poor health. Hunger can also aid maternal death. But what is really responsible for hunger? Poverty has been adjudged to be the main cause of hunger. Hence, it can be noticed from Table 1 that no country is free from poverty even the advanced nations that record high growth rate are plagued by high unemployment which is another indicator of 
poverty. This implies that countries should not rely on growth rate to tackle the menace of poverty but take specific strategies directed towards poverty alleviation. Also to be noticed in table 1 is that the number of people trapped in extreme poverty has increased tremendously in Sub-Saharan Africa. In this table, the Sub-Saharan Africa has 50.9 percent of its population in extreme poverty level. It is the highest percentage out of the regions in the whole world. This is a clear manifestation of the fact that extreme poverty remains an alarming problem in developing country in general and in Sub-Saharan Africa in particular.

Table 1: Poverty Indicator

\begin{tabular}{cccc}
\hline \hline Region & $\begin{array}{c}\text { \% in } \mathbf{\$ 1 . 2 5} \text { a } \\
\text { day poverty }\end{array}$ & $\begin{array}{c}\text { Population } \\
\text { (millions) }\end{array}$ & $\begin{array}{c}\text { Pop. in \$1 a day } \\
\text { poverty (millions) }\end{array}$ \\
\hline East Asia and Pacific & 16.8 & 1,884 & 316 \\
Latin America and the Caribbean & 8.2 & 550 & 45 \\
South Asia & 40.4 & 1,476 & 596 \\
Sub-Saharan Africa & 50.9 & 763 & 388 \\
Total Developing countries & 28,8 & 4673 & 1345 \\
Europe and Central Asia & 0.04 & 473 & 17 \\
Middle East and North Africa & 0.04 & 305 & 11 \\
Total & & $\mathbf{5 4 5 1}$ & $\mathbf{1 3 7 2}$ \\
\hline \hline
\end{tabular}

Source: World Bank PovcalNet "Replicate the World Bank's Regional Aggregation" cited in 2013 World Hunger and Poverty Facts and Statistics.

In Nigeria, it has been asserted that poverty is more devastating in the rural areas where the majority of the population resides. According to the Nigeria Living Standards Survey (NLSS) Report in 2011, 73.2 percent of the rural population is described as poor compared to 61.8 percent in the urban area. In the Southwest, the poverty incidence stood at 49.8 percent in 2010 with Ogun State having the highest incidence (69 percent) in the zone (NBS, 2012, Obisesan and Akinlade, 2013).

Poverty incidence in Nigeria became worse in 1980s. The oil prices downturn in the international market further aggravated the poverty condition in Nigeria. The Government Policy on fuel subsidy removal in 2011 worsens the poverty situation.

Microfinance has been adjudged as a reliable tool for poverty alleviation. It can be used to boost the investment which eventually entails the reduction of poverty and improves the standard of living of the poor (Obisesan and Akinlade, 2013). However, microfinance has been used on several occasions to reduce poverty, in rural areas in particular which are believed to harbour the poorest people in the world. It is an important aid that can improve the economic performance of the poor. The poor people need microfinance to improve their entrepreneurial skill and socio- economic needs. But the poor people could not meet up with the requirements of the conventional banks and 
microfinance is not reachable. They continue to wallop in abject poverty and vicious circle.

This study has its target on the rural poor as statistics have confirmed that the rural sector harbour more poor and impoverished people (Chukwuemeka, 2009). Table 2 depicts the contribution of Urban and Rural sectors to the poverty incidence in Nigeria. Ironically, less than $2 \%$ of rural households have access to financial services (CBN, 2005).

Table 2: Poverty contribution by sector

\begin{tabular}{ccc}
\hline \hline Sector & Incidence & Contribution \\
\hline Urban & 43.2 & 35.0 \\
Rural & 63.3 & 65.0 \\
\hline \hline
\end{tabular}

Source: National Bureau of Statistics (2004) pp22-24 as cited in Chukwuemeka (2009) pp.405-410.

Despite the fact that microfinance has been used for decades as an important development tool and as a formidable programme for poverty alleviation, development practitioners still know little about the possible efficiency of microfinance activities in reducing poverty (Khandker, 2005). Consequently, little efforts have been advanced to study the effect of these programmes on the rural poor particularly in the study area of this research. This exercise will be the foremost study in this geographical area when an independent research will be conducted to study the impact of microfinance on the rural poor. The study is expected to spur the government policy directed to empower the poor with adequate credit facilities and necessary infrastructure for economic development. In this study, an attempt was made to appraise the content and performance of MicroFinance Bank as a catalyst for enhancing economic growth, income redistribution and poverty eradication particularly in South-West Nigeria, having adjudged that MicroFinance Banks have a key role to play in poverty alleviation programmes.

The research study is grouped into five sections. Following the introduction is Section 2 where the previous literature on the subject matter is reviewed. Section 3 enumerates the methodology of the study while section 4 discusses the findings. Section 5 concludes the report with necessary recommendations to the policy makers and other stakeholders.

\section{REVIEW OF PREVIOUS LITERATURE}

Poverty means deprivation from the basic essentials of life. The level of poverty is determined by the income level and degree of inequality among others. The roles of microfinance in poverty reduction have attracted various researchers to the extent that different opinions have been formed. For instance, while some researchers conclude that microfinance loans are mainly used for health, education of school children and production related expenses, others are of the opinion that microfinance has played a 
tremendous role in reducing the depth and incidence of rural poverty and serves as aid for shocks from natural disaster and health related calamities. Even microfinance reduces poverty at the macro level (Anriquez and Stamoulis, 2007).

In view of the fact that Microfinance programmes have been identified as the necessary development strategies to reduce poverty, researchers have made it expedient to carry out studies on the effectiveness of the programmes. To this end, the impact of microfinance loan on poverty reduction has attracted the attention of some scholars in the last three decades. For instance, Khandker and Pitt (1998) studied the impact of microcredit on 1,798 households in Bangladesh and concluded that the loan obtained by women in particular increased the household expenditure, family level of education and good nutrition among others. In the same vein, Morduch (1998) conducted research on the impact of microcredit on about 1,800 microfinance clients and non- client households taken from 1991-92 Cross-sectional survey in Bangladesh. The findings revealed that microfinance loans encourage mild increase in consumption and less vulnerability of the clients to poverty. Also Khandker (2005) conducted research on microfinance and poverty in Bangladesh; and concluded that there is always 20 percent increase on microcredit given to women. The research further emphasised that impact of microfinance is always greater on the extreme poverty than the moderate one and that microfinance accounted for 40 percent of the entire reduction of moderate poverty in rural Bangladesh. Coleman (2002) studied the beneficiaries of microfinance in Northeast Thailand. It was opined that the wealthy people do participate in microfinance loan and become wealthier. Edgcomb and Garber (1998) assessed the microfinance participants and non-participants in Honduras. It was revealed that the profits of microfinance loan participants increased by 75 percent over that of non-participants.

Also, MkNelly and Lippold (1998) assessed the impact of microfinance loan on clients in Mali. The findings revealed that the more the circles or rounds of participation in microfinance, the greater the income. Karlan (2001) discussed the impact of microfinance and concludes that participants' skill in entrepreneurship always enhance prompt loan repayment and business profit. In his study on microfinance in Peru, Alenxander (2001) cited in (Goldberg, 2005) affirms that microcredit assists the poor. Khalily (2004) also agrees that microfinance institutions can achieve the poverty reduction objective through their impact on increase in income, employment generation, increase in consumption of basic necessities, greater acquisition of assets and savings.

Furthermore, in his study of an area in Pakistan on the impact of microfinance on poverty alleviation Ayuub,(2013) concludes that microfinance contributes tremendously in the reduction of poverty, increase of standard of living and income, adequate empowerment, and it also revives the economy. This was agreed upon by Kashif, et al. (2011) who added that microfinance can contribute to the improvement of the business performance of the beneficiary. In the same vein, Shane, (2004) confirms that 
microfinance can enhance the increase in well-being of the borrower with increase in children education and consumption of health services. Assessing the impact of microfinance on the Millennium Development Goals in a district in Pakistan Setboonsarng and Parpiev, (2008) affirm that microfinance has positive impact on production capacity, consumption, assets and Income.

The above studies confirm that microfinance activities have been categorized as an effective development intervention which plays a vital role in poverty reduction.

\section{METHODOLOGY}

To enhance the objectives of this study, primary data were collected between July and September, 2014 from the study area: South-West Nigeria. South-West Nigeria is one of the six geo-political zones in Nigeria with a population of 27,722,432 people out of the Nation`s total population of 140,431,790 (National Population Census, 2006). The zone composed of six states - Ekiti, Lagos, Ogun, Ondo, Osun and Oyo states. However, the vegetation of South-West Nigeria is rainforest with about $12 \%\left(114,271 \mathrm{~km}^{2}\right)$ of Nigeria's coverage space of 923, 768 square kilometers. Microfinance Institutions are much more concentrated in South West Nigeria than any other zone of the country. For instance 346 (about 40\%) of the total 870 Microfinance Institutions in the six geopolitical zones were established in the zone alone, while the balance of sixty percent is shared among the remaining five Geo-political zones.

In addition, cross-sectional data collected through the structured questionnaire were used. Purposive survey was also used to select three out of six states from the Geographical zone namely Ogun, Oyo and Osun states. 1,145 Questionnaires were distributed to the respondents out of which 1,136 were collected from the sampled respondents. 1,134 were effectively used for the analyses; comprising 594 loan beneficiaries and 540 non-beneficiaries. In this context, loan beneficiaries are those individuals who obtained microfinance loan in at least previous three years. While the non-Beneficiaries are those who have similar characteristics with the latter and applied for microfinance loan in the previous three years but could not scale through the process. In this study, an individual beneficiary of microfinance loan is regarded as a derived one from the household perspective. In essence, if one or more members of a household obtain microfinance loan, the entire household is classified as beneficiary (Ashraf and Ibrahim, 2014).

The field survey collated information on the demographic characteristics of the respondents, business and owner's profile, consumption expenditure, loan procurement procedure, assets and business management among others. Furthermore, operators of Microfinance Institutions in the study area were also interviewed on their mode of 
operations, problems faced on the clientele and the assistance required from the Government.

\section{FINDINGS AND DISCUSSIONS}

Table 3 shows the demographics and socio-economic characteristics of the rural poor collected from the sampled area through the surveyed questionnaire. From the total sample size of 1,134 household heads, 594 (52.4\%) are microfinance loan beneficiaries and the remaining $540(47.6 \%)$ are non-beneficiaries. The survey sample comprises $53 \%$ males and $47 \%$ females. In essence, about $51 \%$ of microfinance loan beneficiaries are males while almost $49 \%$ are females; whereas about $56 \%$ of non-beneficiaries are males with around $44 \%$ females. An indication that both loan beneficiaries and nonbeneficiaries have similar gender characteristics.

Considering the education level, the sampled respondents are grouped into five categories. This consists of those with no formal education, those with primary education, those who attended High School, Graduates of National Diploma and those who are degree holders. As depicted in table 3, majority of the respondents have obtained education in one form or the other; about $14 \%$ of the total respondents reported no formal education. The proportion of no formal education for the microfinance loan beneficiaries is $12.5 \%$, lower than that for the non-beneficiaries (15.4\%). About $87.5 \%$ of the microfinance loan beneficiaries and $84.6 \%$ of non-beneficiaries have acquired primary education or more (including High School, National Diploma and Higher Diploma/University degree). Moreover, the proportion of microfinance loan beneficiaries with post High School education (Diploma and Degree) is higher than that of non-beneficiaries (38.7\% against 30.9\%).

The age dimension indicates that the respondents have age range of between 20 and above 60 years old. And the mean age for the sample is around 39 years. A confirmation that most of the respondents are still active and young enough to exhibit their entrepreneurship. When grouped into different age categories, the vast majority of both microfinance loan beneficiaries and non-beneficiaries fall into similar age bracket of 3140 years old ( $46.7 \%$ and $49.5 \%$ respectively).

It was also revealed that a large proportion of the respondents are married $(75.6 \%$ of microfinance loan beneficiaries and $80.2 \%$ of non-beneficiaries). This shows that most of the sampled respondents are responsible to their families and have the tendency to cater for them.

The religion category for the respondents is similar for both Islam and Christianity. Only $2.4 \%$ of microfinance loan beneficiaries have Traditional belief while that of nonbeneficiaries is $7.6 \%$. 
Analysis of the skill/Experience in business entrepreneurship is classified into four categories. The vast majority of the respondents have acquired less than 10 years business experience. While the proportion of the microfinance loan beneficiaries that belong to this category is almost $80 \%$, that of non-beneficiaries is $68 \%$.

Table 3 shows that monthly income for the household head is grouped into five levels. The monthly income for most of the microfinance loan beneficiaries reported is above 30,000 Nigerian Naira (28.3\%) while that of the non-beneficiaries group respondents is between 21,000 and 30,000 Nigerian Naira. Also the household head monthly expenditure of microfinance loan beneficiary group respondents is mainly less than 5,000 Nigerian Naira (41.1\%); most of the household heads monthly expenditure in the non-beneficiary respondents group falls between 5,000 and10,000 Nigerian Naira $(33.2 \%)$.

There is also indication that the proportion of the household size is similar in the sampled survey. About $44 \%$ of microfinance loan beneficiaries have 2-4 persons as members of the household while almost $68 \%$ of non-beneficiaries have $2-4$ persons as members of their households. The survey also revealed that mostly less than 2 persons work and earn income $(49.1 \%)$ in the microfinance loan beneficiary respondents group; while from 2-4 members of the non-beneficiary respondents group mostly work and earn income (64.9\%).

Table 3: Demographic characteristics of respondents

\begin{tabular}{|c|c|c|c|}
\hline \multirow{2}{*}{ Total Sample } & $\begin{array}{l}\text { Non-Beneficiary } \\
\mathrm{N}_{0}=540(47.6 \%)\end{array}$ & $\begin{array}{c}\text { Beneficiary } \\
\mathrm{N}_{1}=594(52.4 \%)\end{array}$ & \multirow{2}{*}{$\begin{array}{c}\text { Total Sample } \\
\mathrm{N}_{3}=1134(100 \%) \\
\text { Subtotal \% to } \mathrm{N}_{4} \\
\mathrm{~N}_{4}=\mathrm{N}_{0}+\mathrm{N}_{1} \\
\end{array}$} \\
\hline & $\%$ to $\mathrm{N}_{0}$ & $\%$ to $\mathrm{N}_{1}$ & \\
\hline \multicolumn{4}{|l|}{ Demography } \\
\hline \multicolumn{4}{|l|}{ Gender } \\
\hline Male & 55.6 & 50.7 & 53 \\
\hline Female & 44.4 & 49.3 & 47 \\
\hline \multicolumn{4}{|l|}{ Education Level } \\
\hline No formal education & 15.4 & 12.5 & 13.8 \\
\hline Primary education & 28.1 & 19.5 & 23.6 \\
\hline High school & 25.6 & 29.3 & 27.5 \\
\hline National Diploma & 18.7 & 20.2 & 19.5 \\
\hline Higher Diploma/University degree & 12.2 & 18.5 & 15.5 \\
\hline \multicolumn{4}{|l|}{ Age (in years) } \\
\hline $20-30$ & 14.3 & 17.1 & 16.1 \\
\hline $31-40$ & 49.5 & 46.7 & 48 \\
\hline $41-50$ & 27.3 & 25.1 & 26.2 \\
\hline $51-60$ & 6.5 & 8.7 & 7.6 \\
\hline$>60$ & 2.4 & 2.6 & 2.7 \\
\hline Mean Age & 39.25 & 39.19 & 39.22 \\
\hline
\end{tabular}


Table 3: Demographic characteristics of respondents (con't)

\begin{tabular}{|c|c|c|c|}
\hline \multirow{2}{*}{ Total Sample } & $\begin{array}{l}\text { Non-Beneficiary } \\
\mathrm{N}_{0}=540(47.6 \%)\end{array}$ & $\begin{array}{c}\text { Beneficiary } \\
\mathrm{N}_{1}=\mathbf{5 9 4}(\mathbf{5 2 . 4 \%}) \\
\end{array}$ & $\begin{array}{c}\text { Total Sample } \\
\mathrm{N}_{3}=1134(\mathbf{1 0 0 \%})\end{array}$ \\
\hline & $\%$ to $\mathrm{N}_{0}$ & $\%$ to $\mathrm{N}_{1}$ & $\begin{array}{l}\text { Subtotal \% to } \mathrm{N}_{4} \\
\quad \mathrm{~N}_{4}=\mathrm{N}_{0}+\mathrm{N}_{1}\end{array}$ \\
\hline \multicolumn{4}{|l|}{ Marital Status } \\
\hline Single & 11.3 & 17.0 & 14.3 \\
\hline Married & 80.2 & 75.6 & 77.8 \\
\hline Divorced & 5.9 & 3.9 & 4.9 \\
\hline Widow & 1.9 & 3.2 & 2.6 \\
\hline Widower & .7 & -3 & .5 \\
\hline \multicolumn{4}{|l|}{ Religion } \\
\hline Islam & 44.2 & 40.8 & 42.5 \\
\hline Christianity & 48.2 & 56.8 & 52.7 \\
\hline Traditional & 7.6 & 2.4 & 4.8 \\
\hline \multicolumn{4}{|l|}{ Household Profile } \\
\hline \multicolumn{4}{|c|}{ Skill/Experience in Business (in years) } \\
\hline$\leq 10$ & 68.1 & 80.0 & 74.3 \\
\hline $11-20$ & 29 & 18.4 & 23.5 \\
\hline $21-30$ & 2.3 & 1.7 & 2.0 \\
\hline$>30$ & .8 & .2 & .5 \\
\hline Mean Experience in Business & 9.4 & 7.81 & 8.57 \\
\hline \multicolumn{4}{|l|}{ Monthly Income } \\
\hline Less than N5000 & 13.1 & 14.1 & 13.7 \\
\hline N5000 - N10000 & 11.7 & 21.0 & 16.6 \\
\hline N11000 - N20000 & 24.4 & 19.2 & 21.7 \\
\hline N21000 - N30000 & 27.2 & 17.3 & 22.0 \\
\hline Above N300000 & 23.5 & 28.3 & 26.0 \\
\hline \multicolumn{4}{|l|}{ Monthly Expenditure } \\
\hline Less than N5000 & 24.9 & 41.1 & 33.4 \\
\hline N5000 - N10000 & 33.2 & 24.5 & 28. \\
\hline N11000 - N20000 & 30.6 & 18.5 & 24.3 \\
\hline N21000 - N30000 & 5.8 & 7.3 & 6.5 \\
\hline Above N30000 & 5.6 & 8.6 & 7.2 \\
\hline \multicolumn{4}{|l|}{ Household Size } \\
\hline$<2$ persons & 13.5 & 28.5 & 21.4 \\
\hline $2-4$ persons & 67.5 & 44.3 & 55.3 \\
\hline $5-7$ persons & 17.4 & 23.6 & 20.7 \\
\hline $8-10$ persons & 1.1 & 3.4 & 2.3 \\
\hline Above 10 persons & .4 & .3 & .4 \\
\hline \multicolumn{4}{|l|}{ Number of Income Earners } \\
\hline$<2$ persons & 27.5 & 49.1 & 38.8 \\
\hline $2-4$ persons & 64.9 & 42.2 & 53.0 \\
\hline $5-7$ persons & 7.4 & 7.8 & 7.6 \\
\hline $8-10$ persons & .2 & 1.0 & .6 \\
\hline
\end{tabular}

Source: Field Survey Data (2014) 
Table 4 shows the cross-tabulations of the percentages of some of the variables that can be used to measure the level of poverty. As depicted in table 4, the acronym in the first column $\left(\mathrm{BN}_{1}\right)$ indicates the percentage characteristics of microfinance loan beneficiaries before obtaining the loan; column two $\left(\mathrm{NBN}_{1}\right)$ shows the same characteristics of nonbeneficiaries before applying for the loan. In the same vein, column three $\left(\mathrm{BN}_{2}\right)$ shows the percentage characteristics of microfinance loan beneficiaries after obtaining the loan while column four $\left(\mathrm{NBN}_{2}\right)$ indicates the same for non-beneficiaries after the application for the loan. Column five $\left(D_{1}\right)$ shows the difference in percentages of the microfinance loan beneficiaries before and after obtaining the loan with regards to the listed variables; while column six $\left(D_{2}\right)$ shows the same characteristics for non-beneficiaries before and after the application for the loan. Column seven shows the difference in the differences that indicate the final results. The negative signs in the last column indicate the situation where the percentage increase in the difference characteristics of the non-loan beneficiaries is higher than that of loan beneficiaries. Conversely, the positive signs in the last column can be interpreted that the situation portrays more difference in the

Table 4: Impact of Microfinance

\begin{tabular}{|c|c|c|c|c|c|c|c|}
\hline & \multicolumn{2}{|c|}{ Before } & \multicolumn{2}{|c|}{ After } & \multirow{2}{*}{$\frac{\mathrm{D}_{1}}{\mathrm{BN}_{2}-\mathrm{BN}_{1}}$} & \multirow{2}{*}{$\begin{array}{c}\mathrm{D}_{2} \\
\mathrm{NBN}_{2}-\mathrm{NBN}_{1}\end{array}$} & \multirow{2}{*}{$\frac{D_{1}-D_{2}}{\%}$} \\
\hline & $\mathbf{B N}_{1}$ & $\mathrm{NBN}_{1}$ & $\mathbf{B N}_{2}$ & $\mathbf{N B N}_{2}$ & & & \\
\hline \multicolumn{8}{|l|}{ Education } \\
\hline No formal education & 12.5 & 15.4 & 12.0 & 15.4 & $-(0.5)$ & 0 & -0.5 \\
\hline Primary education & 19.5 & 28.1 & 16.7 & 27.2 & $-(2.8)$ & $-(0.9)$ & -1.9 \\
\hline High school & 29.3 & 25.6 & 27.4 & 22.0 & $-(1.9)$ & $-(3.6)$ & 1.7 \\
\hline National Diploma & 20.2 & 18.7 & 17.8 & 15.9 & $-(2.4)$ & $-(2.8)$ & 0.4 \\
\hline Higher Diploma/University degree & 18.5 & 12.2 & 26.1 & 19.4 & 7.6 & 7.2 & 0.4 \\
\hline \multicolumn{8}{|l|}{ Household Size } \\
\hline Less than 2 persons & 28.5 & 13.5 & 26.1 & 9.1 & $-(2.4)$ & $-(4.4)$ & 2 \\
\hline $2-4$ persons & 44.3 & 67.5 & 43.9 & 68.8 & $-(0.4)$ & 1.3 & -1.7 \\
\hline $5-7$ persons & 23.6 & 17.4 & 25.4 & 18.6 & 1.8 & 1.2 & -5 \\
\hline $8-10$ persons & 3.4 & 1.1 & 3.7 & 3.0 & 0.3 & 1.9 & 0.6 \\
\hline Above 10 persons & .3 & .4 & .8 & .6 & 0.5 & 0.2 & 0.3 \\
\hline \multicolumn{8}{|l|}{ Daily Sales } \\
\hline Less than N50,000 & 73.2 & 85.5 & 70.9 & 81.6 & $-(2.3)$ & $-(3.9)$ & 1.6 \\
\hline $\mathrm{N} 50,000$ - N100,000 & 16.5 & 10.9 & 15.1 & 9.6 & $-(1.4)$ & $-(1.3)$ & -0.1 \\
\hline $\mathrm{N} 101,000$ - N300,000 & 7.0 & 3.2 & 7.4 & 5.2 & 0.4 & 2 & -1.6 \\
\hline $\mathrm{N} 301,000$ - N500,000 & 2.1 & .2 & 4.4 & 2.4 & 2.3 & 2.2 & 0.10 .2 \\
\hline Above N500,000 & 1.2 & .2 & 2.3 & 1.1 & 1.1 & 0.9 & \\
\hline \multicolumn{8}{|l|}{ Monthly Income } \\
\hline Less than N5000 & 14.1 & 13.1 & 5.9 & 8.3 & $-(8.2)$ & $-(4.8)$ & -3.4 \\
\hline N5000 - N10000 & 21.0 & 11.7 & 17.5 & 9.4 & $-(3.5)$ & $-(2.3)$ & -1.2 \\
\hline N11000 - N20000 & 19.2 & 24.4 & 18.7 & 26.5 & $-(0.5)$ & 7.3 & -7.8 \\
\hline N21000 - N30000 & 17.3 & 27.2 & 18.2 & 26.9 & 0.9 & $-(0.3)$ & 1.2 \\
\hline Above N30000 & 28.3 & 23.5 & 39.7 & 28.9 & 11.4 & 5.4 & 6 \\
\hline \multicolumn{8}{|l|}{ Health Standard } \\
\hline Very poor & .5 & .2 & .3 & 0 & $-(0.2)$ & $-(0.2)$ & 0 \\
\hline Poor & 2.2 & 2.0 & .8 & .2 & $-(1.4)$ & $-(1.8)$ & 0.4 \\
\hline Good & 54.9 & 67.2 & 53.5 & 61.2 & $-(1.4)$ & $-(6)$ & 4.6 \\
\hline Excellent & 42.4 & 30.6 & 45.3 & 38.6 & 2.9 & 8 & -5.1 \\
\hline
\end{tabular}

Source: Field Survey Data (2014). 
differences of the percentage characteristics of the microfinance loan beneficiaries than non-beneficiaries.

Therefore, the overall results revealed that the microfinance beneficiaries have higher level of education, greater increase in household size, greater level of sales, greater level of income and moderate improvement in health standard than the non-beneficiaries from the loan programme. This indicates that microfinance loans extended to the rural poor have transformed their wellbeing. These assertions can be justified by the success glory ascribed to microfinance institutions in some parts of the world. For instance, Amanah Ikhtiar Malaysia (AIM) in Malaysia, Bank of Rakyat in Indonesia and Grameen Bank in Bangladesh (to mention three) have performed creditably towards the poverty reduction and increase in income of the rural poor households in their respective domains. In addition, the notion that microfinance can contribute towards the poverty reduction by increase in income, improved health standard, increase in the level of education and others have been confirmed by various studies (for example, Asghar (2012); Green et.al. (2006); Jha and Dang, (2010); Bashir, et.al., (2010); Muller and Bibi, (2010), Otu and Eko, (2011); Smith, (2010); Arun, et.al (2006); Khalily, (2004).

\section{CONCLUSION AND RECOMMENDATIONS}

This study considers the contributions of microfinance institutions towards the rural poverty reduction in Southwest Nigeria. The outcome of the study revealed that there is marginal contribution of microfinance institutions towards the increase in the welfare of the households in the study area as a result of benefiting from microfinance programmes. This is in line with the findings of Morduch (1998). However, in order to make Microfinance Institutions (MFIs) more effective in the rural poverty reduction and to reach the target poor in the rural areas, the Government should create more enabling environment by improving on the rural physical infrastructural facilities. Also, there has to be constant promotion of health and education facilities. All this would reduce the operational costs of MFIs and make their services in the rural areas more attractive.

Moreover, MFIs should always adjust their loan terms and conditions towards the situation of their potential rural clients. For instance, short term loan and weekly repayment may not augur well for a rural peasant farmer whose harvesting period is seasonal and the crop gestation period is a bit long. In essence, MFIs should endeavor to make flexible client specific repayment schedules. In addition, MFIs can reduce the cost of operation and improve on Corporate Governance by recruiting the local educated people that can earn less than their counterparts in urban centers. Officers from local areas are expected to understand rural poverty better and should be able to convince the poor to join microfinance programmes. 
The issue of security is also paramount in the development process. Nigerian Government should solve the problem of insurgents like "Boko Haram" and "MENDS" in order to ensure peace and stability for economic growth.

\section{REFERENCES}

Alexander, G. (2001). An Empirical Analysis of Microfinance: Who are the clients? Paper presented at the North East Universities Development Consortium (NEUDC) Conference. Boston, 28-30 September, 2001.

Anriquez, G., \& Stamoulis, K. (2007). Rural Development and Poverty Reduction: Is agriculture still the key? ESA Working Paper No.07-02 FAO.

Arun, T., Imai, K., \& Sinha, F. (2006). Does the Microfinance Reduce Poverty in India? Propensity Score Matching based on a National-level Household Data. The University of Manchester Economics Discussion Paper EDP-0625.

Asghar, N. (2012). Microfinancing for Poverty Reduction: An Empirical Study of Rural Areas of Tehsil Gujrat-Pakistan. International Journal of Advances in Management and Economics, 1(4), 14-19.

Ashraf, M. A., \& Ibrahim, Y. B. (2014). Poverty Alleviation and Identifying the Barriers to the Rural Poor Participation in MFIs: A Case Study in Bangladesh. Journal of Economic Cooperation and Development, 35(3), 99-132.

Ayuub, S. (2013). Impact of Microfinance on Poverty Alleviation: A Case Study of NRSP in Bahawalpur of Pakistan, International Journal of Academic Research in Accounting. Finance and Management Sciences, 3(1),119-135.

Bashir, M. K., Amin, A., \& Naeem, M. K. (2010). Micro-credit and Poverty Alleviation in Pakistan. World Applied Sciences Journal, 8(11),1381-1386.

Central Bank of Nigeria (CBN). (2005). Microfinance Policy, Regulatory and Supervisory Framework for Nigeria. Abuja, Nigeria: Central Bank of Nigeria.

Chukwuemeka, E. E. O. (2009). Poverty and the Millennium Development Goals in Nigeria: The Nexus. Educational Research and Review, 4(9), 405-410.

Coleman, B. (2002). Microfinance in Northeast Thailand: Who Benefits and How Much? Manila: Asian Development Bank.

Dimoso, P. J., \& Masanyiwa, Z. S. (2008). A critical look at the role of microfinance banks in poverty reduction in Tanzania: case of Akiba Commercial Bank Limited. Washington, D.C.: Institute of rural Development Planning.

Edgcomb, E., \& Garber, C. (1998). Practitioner-Led Impact Assessment: A Test in Honduras. Washington, D.C.: AIMS.

Food and Agriculture Organization (FAO, WFP and IFAD). (2012). The State of Food Insecurity in the World 2012. Economic Growth is necessary but not sufficient to Accelerate Reduction of Hunger and Malnutrition. Rome, FAO.

Goel, G., \& Rishi, M. (2012). Promoting Entrepreneurship to Alleviate Poverty in India: An Overview of Government Schemes, Private - Sector Programs, and Initiatives in the Citizens' Sector. Thunderbird International Business Review, 54(1), 45-57. 
Goldberg, N. (2005). Measuring the Impact of Microfinance: Taking Stock of What We Know. USA: Grameen Foundation USA Publications Series.

Green, C. J., Kirkpatrick, C. H., \& Murinde, V. (2006). Policy Arena Finance for Small Enterprise Growth and Poverty Reduction in Developing countries. Journal of International Development, 18, 1017-1030.

International Fund for Agricultural Development (IFAD). (2011). Rural Poverty Report 2011. Rome, Italy: IFAD.

Jha, R., \& Dang, T. (2010). Vulnerability to Poverty in Papua New Guinea in 1996. Asian Economic Journal, 24(3), 235-251.

Kalirajan, K., \& Singh, K. (2009). The pace of poverty reduction across the globe: an exploratory analysis. International Journal of Social Economics, 36(6), 692705.

Karlan, D. (2001). Microfinance Impact Assessments: The Perils of Using New Members as a Control Group. Journal of Microfinance, 3(2), 76-85.

Kashif, M., Durrani, K., Malik, M. I., Scholar, P. D., \& Ahmad, S. (2011). Role of MicroFinance in Reducing Poverty: A Look at Social and Economic Factors. Sarhad University of Science and Information Technology Peshawar, 2(21), 138-144.

Khalily, M. A. B. (2004). Quantitative Approach to Impact Analysis of Microfinance Programmes in Bangladesh-What Have We Learned? Journal of International Development, 16(3), 331-353.

Khandker, S. R. (2005). Microfinance and Poverty: Evidence Using Panel Data from Bangladesh. The World Bank Economic Review, 19(2), 263-286.

Khandker, S., \& Pitt, M. (1998). The Impact of Group-Based Credit Programs on Poor Households in Bangladesh: Does the Gender of Participants Matter? Journal of Political Economy, 106(5), 958-996.

MkNelly, B., \& Lippold, K. (1998). Practitioner-Led Impact Assessment: A Test in Mali. Washington, D.C.: AIMS.

Morduch, J. (1998). Does Microfinance Really Help the Poor? New Evidence from Flagship Programs in Bangladesh. Princeton University Working Paper No. 198.

Muller, C., \& Bibi, S. (2010). Refining Targeting against Poverty: Evidence from Tunisia. Oxford Bulletin of Economics and Statistics, 72(3), 381-410.

Mustapha, B., Said, R., Hook, L. S., \& Fahmi, S. S. (2014). The Effects of Structural Change on Rural Poverty in Agrarian Economy: Evidence from Nigeria. Proceedings of National Research and Innovation Conference for Graduate Students in Social Sciences (GS-NRIC December).

National Bureau of Statistics (NBS). (2012). Nigeria Poverty Profile 2010. Nigeria: National Bureau of Statistics.

National Population Commission. (2007). Results of the 2006 Population Census. Abuja, Nigeria: National Population Commission.

Obisesan, A. A., \& Akinlade, R. J. (2013). Credit Constraints and Poverty among Nigerian Farming Households. Agricultural Journal, 8(2), 94-100. 
Oliveira, L. D., Watanabe, E. A., Filho, D. O., \& Sproesser, R. L. (2010). Public Policies for Food Security in Countries With Different Development Levels. International Public Management Network, 11(3), 122-141.

Otu, J. E., Eja, E. I., Eko, J. A., \& Emeka, J. O. (2011). Analysis of Poverty Indices in Underdeveloped Countries: Nigeria Scenario. Mediterranean Journal of Social Sciences, 2(2), 175-183.

Setboonsarng, S., \& Parpiev, Z. (2008). Microfinance and the Millennium Development Goals in Pakistan: Impact Assessment using Propensity Score Matching. ADB Institute Discussion Papers No. 104.

Shane, N. (2004). A Case Study Analysis of the Impacts of Microfinance upon the lives of the Poor in Rural China. Melbourne, Australia: RMIT University.

Smith, N. (2010). Economic inequality and poverty: where do we go from here? International Journal of Sociology and Social Policy, 30(3/4), 127-139.

Ssewamala, F. M., Sperber, E., Zimmerman, J. M., \& Karimli, L. (2010). The potential of asset-based development strategies for poverty alleviation in Sub-Saharan Africa. International Journal of Social Welfare, 19(4), 433-443.

Todaro, P. T., \& Smith, S. C. (2011). Economic Development. England: Pearson.

World Hunger Education Service (WHES). (2013). World Hunger and Poverty Facts and Statistics. Retrieved from http://www.globalissues.org/article/26/poverty-factsand-stats 